\title{
STUDI KASUS ANALISIS BEBAN KERJA BERDASARKAN WAKTU KERJA KARYAWAN PADA UNIT PEMANENAN AFDELING 1 DI KEBUN KELAPA SAWIT PT. XYZ
}

\section{CASE STUDY OF WORKLOAD ANALYSIS BASED ON WORKING TIME OF EMPLOYEES AT HARVESTING UNIT AFDELING 1 IN OIL PALM GARDEN PT. XYZ}

\author{
Muhammad Irwansyah Barkhati Setiawan ${ }^{1 *}$, Arief Rahman ${ }^{1}$, Faradilla ${ }^{1}$, M. Atta Bary ${ }^{1}$ \\ ${ }^{1}$ Politeknik Pertanian Negeri Samarinda \\ Kampus Sei Keledang Jl. Sam Ratulangi Kotak Pos 192, Samarinda, Kalimantan Timur \\ *corresponding muhirwansyah1996@gmail.com
}

\begin{abstract}
The importance of quality human resources in oil palm plantations in the field of harvesting to achieve high productivity, the success of harvesters is also very much determined by the pressure of the workload that is owned by workers, the workload depends on the job description compiled by the company. also the possibility of a workload that is too high. This study aims to analyze the working time of harvest employees and determine the productive, unproductive and personal time of harvest employees and analyze the number of harvest employees needed at PT. XYZ. This research was conducted at PT. XYZ Tanjung Batu Village, Derawan Island District, Berau Regency, East Kalimantan. This research was conducted using work sampling data collection method, namely observing the working time of harvest employees with 10 minutes intervals for 7 working hours by noting productive time, unproductive time and personal time. The results from the observations of researchers through the characteristics of harvest workers that affect the characteristics of age and height characteristics, it is proven that the age of 20 - 29 years is faster to reach the target or basis compared to the age of 30 - 49 years. And the characteristics of height have an effect on reaching the target, it is proven that height $170-179 \mathrm{~cm}$ reaches the target or base faster than $150-159 \mathrm{~cm}$. And the observations of researchers from 16 respondents harvest productive working time an average of $73.52 \%, 17.20 \%$ unproductive time and $9.28 \%$ personal time. Calculation of the need for harvest workers in 1 division (763.33 ha) results in 33,644 rounded up to 34 harvest workers, the results needed in 1 division (763.33 ha) through the calculation of the time of completion of tasks (WPT).
\end{abstract}

Keywords: Workload Analysis, Harvest Employees, Productive Time, Unproductive And Personal.

\section{PENDAHULUAN}

Perkebunan kelapa sawit merupakan salah satu komoditas andalan di Indonesia yang dapat menghasilkan keuntungan besar sehingga banyak hutan dan perkebunan lama dikonversikan menjadi perkebunan kelapa sawit. Penyebaran kelapa sawit di indonesia berada pada pulau sumatra, kalimantan, jawa, sulawesi, papua, dan beberapa pulau tertentu di indonesia. Buah kelapa sawit digunakan sebagai bahan mentah minyak goreng, margarin, sabun, kosmetika, industri farmasi. Bagian yang paling populer untuk di olah dari kelapa sawit adalah buah (Pahan, 2012).

Untuk menghasilkan buah, salah satu kegiatan budidaya yang menjadi kunci utama adalah pemanenan, beberapa hal yang menentukan keberhasilan pemanenan ialah persiapan panen, kriteria matang panen, sistem dan rotasi panen, ramalan produksi, basis dan premi panen, pengawasan dan denda, kebutuhan tenaga kerja serta alat dan 
Setiawan, M.I.B., Rahman, A., Faradilla, dan Barry, M.A. .(2021) "Studi Kasus Analisis Beban Kerja Berdasarkan Waktu Kerja Karyawan Pada Unit Pemanenan Afdeling 1 Di Kebun Kelapa Sawit PT. XYZ", Jurnal Agriment, 6(2).

perlengkapan panen. Apabila semua syarat pemanenan tersebut telah terpenuhi dengan baik maka produktivitas panen dapat meningkat, dan sebaliknya apabila persiapan masih kurang matang, serta masih banyak aspek yang belum terpenuhi maka produktivitas panen akan menurun (Sofiana dan Yahya 2015).

Selain teknis dilapangan seperti yang telah dijelaskan diatas keberhasilan pemanenan juga sangat ditentukan dari tekanan beban kerja yang dimiliki oleh pekerja, sehingga beban kerja dapat dijadikan sebagai salah satu acuan untuk mengetahui produktivitas panen, beban kerja dibagi menjadi tiga kondisi yaitu, pertama beban kerja yang sesuai dengan standar, kedua beban kerja yang terlalu tinggi, ketiga beban kerja yang terlalu rendah. Ketiga beban kerja tersebut tergantung dari deskripsi pekerjaan yang disusun oleh perusahaan. Semakin banyak deskripsi pekerjaan yang diselesaikan oleh karyawan, maka semakin tinggi pula kemungkinan terjadinya beban kerja yang terlalu tinggi demikian juga sebaliknya (Suwanto dan Priansa, 2011).

Tujuan dari penelitian ini untuk $m$ menganalisis waktu kerja karyawan panen di afdeling 1 PT. XYZ. dan menganalisis jumlah karyawan panen yang dibutuhkan di afdeling $1 \mathrm{PT}$. XYZ.

\section{METODOLOGI}

Penelitian ini dilaksanakan di PT.XYZ di Desa Tanjung Batu, Kecamatan Pulau Derawan, Kabupaten Berau Kalimantan Timur. Pengambilan sampel menggunakan purposive sampling. Sampel berupa karyawan panen di afdeling 1 dengan jumlah 16 orang atau $50 \%$ dari total 33 orang karyawan pemanenan yang ada di lapangan. Berdasarkan pendapat (Sujahweni, 2015) apabila populasi kurang lebih 100, maka jumlah sampel sekurangkurangnya $50 \%$ dari ukuran populasi.

Metode pengumpulan data primer yang dilakukan adalah observasi dan wawancara di lapangan ketika melakukan perkerjaan. Kemudian mengamati waktu kerja menggunakan work sampling adalah pengamatan yang dilakukan peneliti terhadap aktivitas yang dilakukan oleh karyawan selama jam kerja yang ditetapkan oleh perusahaan dengan interval waktu pengamatan 10 menit, pengumpulan data berupa foto dan rekaman kegiatan lapangan serta wawancara untuk menentukan karakteristik pada karyawan panen dan tujuan mengetahui karakteristik karyawan mengacu pada sebuah tesis (Bary dkk., 2013) adalah pengukuran beban kerja diawali dengan mengukur karakteristik responden yang dicocokan berdasarkan waktu kerja produktif, tidak produktif dan pribadi yang dilakukan karyawan dalam melaksanakan pekerjaan untuk mengetahui apakah karakteristik responden berpengaruh terhadap waktu kerja dalam menyelesaikan target kerja.

Beban kerja dapat dihitung melalui metode work sampling, work sampling digunakan untuk mengukur aktifitas pegawai dengan menghitung waktu yang digunakan untuk bekerja dan waktu yang tidak digunakan untuk bekerja dalam jam kerja mereka, kemudian disajikan dalam bentuk persentase (Handoko, 2017). Metode work sampling mengamati apa yang dilakukan oleh responden dan informasi yang dibutuhkan dalam penelitian yang berisikan waktu kegiatan dan kegiatannya. Adapun tiga kegunaan utama dari work sampling diantaranya adalah:

1. Activity and Delay Sampling, yaitu untuk mengukur aktifitas dan penundaan aktifitas dari seorang pekerja. Contohnya adalah dengan mengukur persentase seseorang 
bekerja dan persentase seseorang tidak bekerja.

2. Performance Sampling, yaitu untuk mengukur waktu yang digunakan untuk bekerja, dan waktu yang tidak digunakan untuk bekerja.

3. Work Measurement, untuk menetapkan waktu standar dari suatu kegiatan.

Tahapan-tahapan yang harus dilaksanakan dalam melakukan survey pekerjaan dengan work sampling diantaranya adalah:

1. Menentukan jenis responden yang akan diteliti.

2. Apabila jumlah responden banyak, maka perlu dilakukan pemilihan sampel sebanyak $50 \%$ dari jumlah karyawan sebagai subjek responden yang akan diamati.

3. Membuat formulir daftar kegiatan.

4. Melatih pelaksana peneliti mengenai tata cara pengamatan kerja dengan menggunakan work sampling. Setiap pelaksana peneliti mengamati 1 responden yang sedang bekerja.

5. Pengamatan dilakukan dengan interval 10 menit tergantung karakteristik pekerjaan.

\section{Analisi Data}

Menetapkan Waktu Kerja Waktu kerja yang dimaksud adalah waktu kerja efektif, artinya waktu kerja yang secara efektif digunakan untuk bekerja. Waktu kerja efektif terdiri atas hari kerja efektif dan jam kerja efektif. Menurut Roidelindho, 2017 hari kerja efektif adalah jumlah hari dalam kalender dikurangi hari libur hari jum'at dan cuti. Perhitungannya adalah sebagai berikut:

Hari Kerja Efektif $=\{A-(B+C+D+E)\}$

Keterangan:

$A=$ Jumlah hari menurut kalender

$\mathrm{B}=$ Jumlah hari minggu dalam setahun

$\mathrm{C}=$ Jumlah hari libur dalam setahun

$\mathrm{D}=$ Jumlah cuti tahunan

$\mathrm{E}=$ Jumlah hari jum'at dalam setahun
Menyusun Waktu Penyelesaian Tugas Menurut Novera 2017 waktu penyelesaian tugas merupakan hasil perkalian dari jumlah beban suatu tugas pokok dengan standar kemampuan ratarata waktu yang digunakan dalam penyelesaian tugas tersebut. Dihitung berdasarkan semua bentuk pekerjaan dalam unit panen yang dikerjakan oleh karyawan panen dan terdapat jumlah waktu yang digunakan karyawan panen dalam menyelesaikan kerja tersebut yang disajikan sebagai berikut:

Tabel 1. Rumus Perhitungan Waktu Penyelesaian Tugas

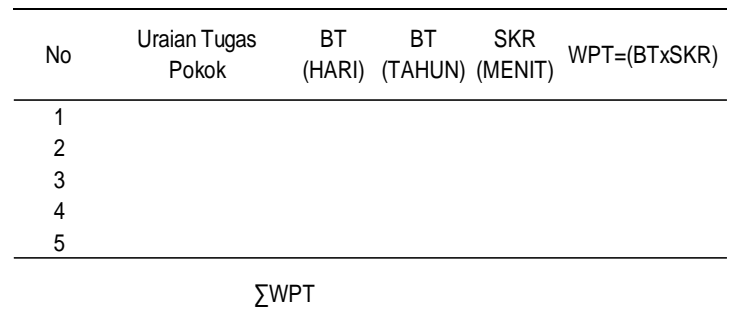

Keterangan :

BT = Jumlah beban tugas dalam waktu tertentu

SKR = Standar kemampuan rata - rata waktu penyelesaian tugas

WPT = Waktu penyelesaian tugas

Menghitung Jumlah Kebutuhan Pekerja, jumlah kebutuhan pekerja dengan demikian dapat dihitung setelah waktu penyelesaian tugas dan waktu kerja efektif ditentukan. Rumus perhitungan jumlah kebutuhan pekerja sebagai berikut:

Kebutuhan Pekerja $\frac{\sum \text { Waktu Penyelesaian Tugas }}{\sum \text { Waktu Kerja Efektif }}$ X Jumlah Karyawan

\section{HASIL DAN PEMBAHASAN}

\section{Karakteristik Berdasarkan Jenis Kelamin}

Berdasarkan tabel 2 dapat diketahui bahwa karyawan panen yang menjadi responden berjumlah 16 orang berjenis kelamin laki-laki, dalam pekerjaan panen hal yang terpenting adalah kekuatan fisik dalam memotong pelepah dan tandan buah segar menggunakan 
Setiawan, M.I.B., Rahman, A., Faradilla, dan Barry, M.A. .(2021) "Studi Kasus Analisis Beban Kerja Berdasarkan Waktu Kerja Karyawan Pada Unit Pemanenan Afdeling 1 Di Kebun Kelapa Sawit PT. XYZ", Jurnal Agriment, 6(2).

egrek dan pengeluaran buah ke TPH yang membutuhkan tenaga banyak yang lebih dominan ke laki-laki dalam hal kekuatan fisik.

\section{Karakteristik Berdasarkan Usia (Tahun)}

Usia sangat berpengaruh terhadap penggunaan waktu dalam mencapai target yang telah ditetapkan oleh perusahaan terlihat pada tabel 2, terbukti di lapangan dengan rentang usia 20 - 29 tahun lebih cepat mencapai target atau basis dibandingkan dengan usia 30 - 39 tahun dan umur 40 - 49 tahun karena kondisi fisik yang berbeda usia muda dan tua. Penentuan tersebut dilihat melalui pengelompokan usia 20 tahun, 30 tahun dan 40 tahun karena jarak 10 tahun cukup mendapatkan pertimbangan bahwa usia tersebut mendapatkan pengaruh terhadap penggunaan waktu kerja pada umumnya sesuai dengan pernyataan.

\section{Karakteristik Berdasarkan Tinggi Badan}

Berdasarkan tinggi badan karyawan panen pada tabel 2 berpengaruh terhadap penggunaan waktu dalam mencapai target yang telah ditetapkan oleh perusahaan dengan usia tanaman $9-11$ tahun (tinggi pokok $5-10$ meter), terbukti di lapangan dari tinggi badan $170-179 \mathrm{~cm}$ lebih cepat mencapai target dibandingkan dengan tinggi badan $150-159 \mathrm{~cm}$ dan $160-169 \mathrm{~cm}$..

\section{Karakteristik Berdasarkan Berat Badan}

Berat badan karyawan panen tidak berpengaruh terhadap penyelesaian target yang telah ditentukan oleh perusahaan dapat dilihat pada tabel 2 . Terbukti karyawan yang mempunyai timbangan 50 - $59 \mathrm{~kg}, 60$ - $69 \mathrm{~kg}$ dan 70 $79 \mathrm{~kg}$ lebih cepat tercapai target dari pada karyawan panen yang mempunyai timbangan 40 - $49 \mathrm{~kg}$. hal tersebut banyak faktornya, karyawan panen yang mempunyai berat badan 40 - $49 \mathrm{~kg}$ banyak melakukan waktu tidak produktif dibandingkan dengan karyawan panen yang mempunyai berat badan $>50 \mathrm{~kg}$. Apabila berat badan yang rendah lebih lincah dari pada berat badan yang berat.

\section{Karakteristik Berdasarkan Lama Kerja Lama kerja karyawan tidak terlalu} berpengaruh terhadap penyelesaian waktu kerja yang telah ditentukan oleh perusahaan. Berdasarkan tabel 2, terbukti dari karyawan yang mempunyai pengalaman kerja lebih lama di $>8,1$ tahun tidak terlalu cepat menyelesaikan target yang telah ditentukan hal tersebut karena karyawan banyak melakukan waktu tidak produktif selama jam kerja, dibandingkan lama kerja 4,1 - 6 tahun kerja yang mana lebih cepat menyelesaikan target. Menurut Wijaya (2014) secara umum bahwa pengalaman lama kerja sangat berpengaruh dalam waktu penyelesaian kerja karena lebih menguasai pekerjaan tersebut dibandingkan karyawan yang kurang pengalaman kerjanya.

\section{Karakteristik Berdasarkan Tingkat Pendidikan}

Berdasarkan tabel 2 bahwa karyawan panen tidak memiliki pendidikan 1 (Tidak Sekolah), 9 SD, 3 SMP dan 3 SMA. Pada bidang pemanenan ini sekolah/pendidikan tidak terlalu berpengaruh pada produktivas panen. Karena pada bidang panen ini yang di butuhkan dominan ke tenaga/fisik.

\section{Penggunaan Waktu Kerja}

Berdasarkan tabel 3 merupakan data yang didapat dari lapangan dimana data tersebut diolah menjadi persentase yang dikategorikan masing-masing waktu produktif, tidak produktif dan pribadi. Berdasarkan tabel 4 waktu produktif karyawan panen mempunyai persentase rata-rata mencapai $73,52 \%$ setara dengan 289 menit, waktu tidak produktif mencapai $17,20 \%$ setara dengan 68 menit dan waktu pribadi mencapai 9,28\% setara 38 menit ). Waktu Produktif tertinggi pada kp 1 dan kp 
6 , waktu tidak produktif tertinggi pada $\mathrm{kp}$ 11 dan $\mathrm{kp} 15$ serta waktu pribadi tertinggi pada kp 7 dan $\mathrm{kp} 13$. Sesuai dengan pernyataan Yasin (2020) waktu kelonggaran (allowance) sekitar 30\% (waktu tidak produkti dan pribadi) untuk pekerjaan panen atau pekerjaan yang sangat berat. Waktu Produktif tergolong standar di angka $73,52 \%$ waktu kerja produktif seseorang optimum mencapai $70 \%$ sesuai dengan pengurangan allowance $30 \%$ apabila beban kerja tersebut lebih berat.

Tabel 2. Karakteristik Karyawan Panen

\begin{tabular}{|c|c|c|c|}
\hline Variabel & Keterangan & $\begin{array}{c}\text { Jumlah } \\
\text { Karyawan }\end{array}$ & $\begin{array}{c}\text { Persentase } \\
(\%)\end{array}$ \\
\hline \multirow{3}{*}{$\begin{array}{c}\text { Jenis } \\
\text { Kelamin }\end{array}$} & Laki-Laki & 16 & $100 \%$ \\
\hline & Perempuan & - & $0 \%$ \\
\hline & Jumlah Kp & 16 & $100 \%$ \\
\hline \multirow{4}{*}{ Usia } & $20-29$ & 3 & $18,75 \%$ \\
\hline & $30-39$ & 8 & $50 \%$ \\
\hline & $40-49$ & 5 & $31,25 \%$ \\
\hline & Jumlah Kp & 16 & $100 \%$ \\
\hline \multirow{4}{*}{$\begin{array}{l}\text { Tinggi } \\
\text { Badan }\end{array}$} & $150-159$ & 3 & $18,75 \%$ \\
\hline & $160-169$ & 6 & $37,50 \%$ \\
\hline & $170-179$ & 7 & $43,75 \%$ \\
\hline & Jumlah Kp & 16 & $100 \%$ \\
\hline \multirow{5}{*}{$\begin{array}{l}\text { Berat } \\
\text { Badan }\end{array}$} & $40-49$ & 1 & $6,25 \%$ \\
\hline & $50-59$ & 2 & $12,50 \%$ \\
\hline & $60-69$ & 10 & $62,50 \%$ \\
\hline & $70-79$ & 3 & $18,75 \%$ \\
\hline & Jumlah Kp & 16 & $100 \%$ \\
\hline \multirow{6}{*}{$\begin{array}{l}\text { Lama } \\
\text { Kerja }\end{array}$} & $0-2$ & 4 & $25 \%$ \\
\hline & $2,1-4$ & 4 & $25 \%$ \\
\hline & $4,1-6$ & 3 & $18,75 \%$ \\
\hline & $6,1-8$ & 2 & $12,50 \%$ \\
\hline & $>8$ & 3 & $18,75 \%$ \\
\hline & Jumlah Kp & 16 & $100 \%$ \\
\hline \multirow{5}{*}{$\begin{array}{c}\text { Tingkat } \\
\text { Pendidik } \\
\text { an }\end{array}$} & Tidak Sekolah & 1 & $6,25 \%$ \\
\hline & SD & 9 & $56,25 \%$ \\
\hline & SMP & 3 & $18,75 \%$ \\
\hline & SMA & 3 & $18,75 \%$ \\
\hline & Jumlah Kp & 16 & $100 \%$ \\
\hline
\end{tabular}

\section{Waktu Kerja Efektif}

Perhitungan hari kerja efektif pada tahun 2020 ialah, 1 tahun mempunyai 365 hari dan hari minggu 52 hari, libur nasional
16 hari, cuti tahunan 12 hari dan hari jum'at sebanyak 52 hari. Sehingga total hari dalam 1 tahun dikurang hari libur diperolehlah hari kerja efektif sebanyak 285 hari. Karyawan panen bekerja dari hari senin, selasa, rabu, kamis dan sabtu selama 7 jam perhari atau setara dengan 420 menit. Di hari jum'at karyawan panen bekerja selama 5 jam perhari atau setara dengan 300 menit. 420 menit $\times 233$ hari $=$ 97.860 menit (WKE hari Senin, Selasa, Rabu, Kamis, Sabtu) dan 300 menit x 52 hari $=15.600$ menit (WKE hari jum'at). 97.860 menit +15.600 menit $=113.460$ menit dapatlah nilai dari perhitungan waktu kerja efektif (WKE) dalam 1 tahun.

Tabel 3. Persentase Penggunaan Waktu Kerja

\begin{tabular}{|c|c|c|c|c|c|c|}
\hline \multirow{2}{*}{ Responden } & \multicolumn{3}{|c|}{ Total Waktu (Menit) } & \multicolumn{3}{|c|}{ Persentase } \\
\hline & $\mathrm{P}$ & TP & $\mathrm{PD}$ & $\mathrm{P}$ & TP & PD \\
\hline Kp 1 & 367 & 26 & 27 & 87,38 & 6,19 & 6,43 \\
\hline $\mathrm{Kp} 2$ & 288 & 62 & 30 & 75,79 & 16,32 & 7,89 \\
\hline Kp 3 & 298 & 52 & 30 & 78,42 & 13,68 & 7,89 \\
\hline Kp 4 & 279 & 59 & 42 & 73,42 & 15,53 & 11,05 \\
\hline Kp 5 & 276 & 60 & 44 & 72,63 & 15,79 & 11,58 \\
\hline Kp 6 & 338 & 27 & 15 & 88,95 & 7,11 & 3,95 \\
\hline $\mathrm{Kp} 7$ & 310 & 40 & 70 & 73,81 & 9,52 & 16,67 \\
\hline Kp 8 & 337 & 35 & 48 & 80,24 & 8,33 & 11,43 \\
\hline Kp 9 & 266 & 112 & 2 & 70,00 & 29,47 & 0,53 \\
\hline Kp 10 & 244 & 107 & 29 & 64,21 & 28,16 & 7,63 \\
\hline Kp 11 & 219 & 180 & 21 & 52,14 & 42,86 & 5,00 \\
\hline Kp 12 & 311 & 31 & 38 & 81,84 & 8,16 & 10,00 \\
\hline Kp 13 & 192 & 131 & 57 & 50,53 & 34,47 & 15,00 \\
\hline Kp 14 & 306 & 33 & 41 & 80,53 & 8,68 & 10,79 \\
\hline Kp 15 & 256 & 120 & 44 & 60,95 & 28,57 & 10,48 \\
\hline Kp 16 & 325 & 9 & 46 & 85,53 & 2,37 & 12,11 \\
\hline Jumlah & 4612 & 1084 & 584 & 1176,37 & 275,21 & 148,42 \\
\hline Rata-Rata & 289 & 68 & 38 & 73,52 & 17,20 & 9,28 \\
\hline $\begin{array}{ll}\text { Keteranga } \\
\mathrm{P}\end{array}$ & $\begin{array}{l}\text { Pr: } \\
\text { Produ } \\
\text { Tidak } \\
\text { Priba }\end{array}$ & $\begin{array}{l}\text { ktif } \\
\text { Pro }\end{array}$ & & & & \\
\hline
\end{tabular}


Setiawan, M.I.B., Rahman, A., Faradilla, dan Barry, M.A. .(2021) "Studi Kasus Analisis Beban Kerja Berdasarkan Waktu Kerja Karyawan Pada Unit Pemanenan Afdeling 1 Di Kebun Kelapa Sawit PT. XYZ", Jurnal Agriment, 6(2).

Tabel 4. Perhitungan Hari Kerja Efektif dalam 1 tahun

\begin{tabular}{llcccccc}
\hline No & Bulan & JH & HM & LN & C & HK. EJ & HKE \\
\hline 1 Januari & 31 & 5 & 1 & 1 & 5 & 19 \\
2 Febuari & 28 & 4 & 1 & 1 & 4 & 18 \\
3 Maret & 31 & 4 & 2 & 1 & 4 & 20 \\
4 April & 30 & 4 & 1 & 1 & 4 & 20 \\
5 Mei & 31 & 5 & 5 & 1 & 5 & 15 \\
6 Juni & 30 & 4 & 1 & 1 & 4 & 20 \\
7 Juli & 31 & 4 & 1 & 1 & 5 & 20 \\
8 Agustus & 31 & 5 & 2 & 1 & 4 & 19 \\
9 September & 30 & 4 & - & 1 & 4 & 21 \\
10 Oktober & 31 & 5 & 1 & 1 & 5 & 19 \\
11 & November & 30 & 4 & - & 1 & 4 & 21 \\
12 & Desember & 31 & 4 & 1 & 1 & 4 & 21 \\
\hline \multicolumn{2}{c}{ Jumlah } & 365 & 52 & 16 & 12 & 52 & 233 \\
\hline
\end{tabular}

Keterangan:

$\mathrm{JH} \quad=$ Jumlah Hari

$\mathrm{HM} \quad=$ Hari Minggu

LN $\quad=$ Libur Nasional

$\mathrm{C} \quad=$ Cuti

HKEJ = Hari Kerja Efektif Jumat
HKE = Hari Kerja Efektif

\section{Pengukuran Kebutuhan Karyawan Panen Kelapa Sawit.}

Kebutuhan karyawan panen di afdeling 1 mengikuti luasan 763,33 ha maka dapatlah total kebutuhan tenaga kerja di afdeling 1 melalui pembagian 115.676 menit (WPT) dengan 113.460 menit (WKE) dikali 33 (total karyawan aktual) dengan hasil 33,644 yang dibulatkan menjadi 34 karyawan panen karena kelebihan beban kerja yaitu 0,644, sehingga harus dilakukan pembulatan 1 menjadi 34 karyawan untuk tercapainya produktivitas yang baik. Maka secara perhitungan ada penambahan karyawan berjumlah 1 orang karena beban kerja yang dihitung lebih berat dibandingkan total jumlah karyawan yang ada.

Tabel 5. Waktu Penyelesaian Tugas Karyawan Panen

\begin{tabular}{|c|c|c|c|c|c|c|}
\hline \multicolumn{2}{|l|}{ Responden } & \multirow[t]{2}{*}{ Uraian Kegiatan } & \multirow{2}{*}{$\begin{array}{c}\begin{array}{c}\mathrm{BT} \\
\text { (Hari) }\end{array} \\
1\end{array}$} & \multirow{2}{*}{$\begin{array}{c}\text { BT } \\
\text { (Tahun) } \\
285\end{array}$} & \multirow{2}{*}{$\begin{array}{c}\begin{array}{c}\text { SKR } \\
\text { (Menit) }\end{array} \\
5\end{array}$} & \multirow{2}{*}{$\begin{array}{c}\begin{array}{c}\text { WPT } \\
\text { (Menit/Tahun) }\end{array} \\
1.425\end{array}$} \\
\hline Karyawan & 1 & & & & & \\
\hline $\begin{array}{l}\text { Pemanena } \\
\text { n TBS }\end{array}$ & 2 & $\begin{array}{l}\text { Pengarahan dan masukan Asisten Afdeling kepada } \\
\text { seluruh Karyawan. }\end{array}$ & 1 & 285 & 5 & 1.425 \\
\hline $\begin{array}{l}\text { (Tandan } \\
\text { Buah }\end{array}$ & 3 & $\begin{array}{l}\text { Pengarahan mandor panen kepada karyawan } \\
\text { panen tentang blok yang akan dipanen. }\end{array}$ & 1 & 285 & 5 & 1.425 \\
\hline $\begin{array}{l}\text { Segar) } \\
\text { Kelapa }\end{array}$ & 4 & $\begin{array}{l}\text { Persiapan alat kerja dan bekal yang akan dibawa } \\
\text { oleh karyawan panen. }\end{array}$ & 1 & 285 & 5 & 1.425 \\
\hline \multirow[t]{8}{*}{ Sawit } & 5 & $\begin{array}{l}\text { Keberangkatan menuju lokasi blok dan ancak yang } \\
\text { akan dipanen. }\end{array}$ & 1 & 285 & 6,33 & 1.804 \\
\hline & 6 & $\begin{array}{l}\text { Pemanenan dimulai memasuki ancak dan } \\
\text { membawa alat egrek. }\end{array}$ & 1 & 285 & 1 & 285 \\
\hline & 7 & $\begin{array}{l}\text { Pemotong pelepah dan TBS kelapa sawit yang } \\
\text { brondol }>1 \text { (Matang). }\end{array}$ & 211 & 285 & 0,37 & 22.250 \\
\hline & 8 & $\begin{array}{l}\text { Pengumpulan buah dan brondolan TBS yang telah } \\
\text { dipanen menggunakan arco dan loding/tojok. }\end{array}$ & 21 & 285 & 4,28 & 25.616 \\
\hline & 9 & $\begin{array}{l}\text { Peletakan dan Penyusunan Buah pada TPH } \\
\text { dengan rapi. }\end{array}$ & 211 & 285 & 0,5 & 30.068 \\
\hline & 10 & Pemotongan tangkai panjang pada TBS $>2 \mathrm{~cm}$. & 171 & 285 & 0,6 & 29.241 \\
\hline & 11 & $\begin{array}{l}\text { Pemberian Nama pada TPH buah untuk } \\
\text { memudahkan Checker atau krani buah. }\end{array}$ & 1 & 285 & 0,5 & 143 \\
\hline & 12 & Perpindahan ke ancak selanjutnya. & 1 & 285 & 2 & 570 \\
\hline & & $\Sigma W P T$ & & & & 115.676 \\
\hline
\end{tabular}

Keterangan:

BT = Beban Tugas

SKR = Standar Kemampuan Rata-rata

WPT $=$ Waktu Penyelesaian Tugas 
doi.org/10.51967/jurnalagriment.v6i2.578 (C) 2021 Politeknik Pertanian Negeri Samarinda Naskah ini dilisensikan Creative Commons Attribution 4.0 License CC-BY SA

$\overline{\text { Kebutuhan Pekerja }=\frac{\sum \text { Waktu Penyelesaian Tugas }}{\Sigma \text { Waktu Kerja Efektif }} \quad X \text { Jumlah Karyawan }}$

$$
\begin{aligned}
& =\quad \frac{115.676 \text { menit }}{113.460 \text { menit }} \times 33 \\
& =\quad 1.01953111 \times 33=33,644=34
\end{aligned}
$$

\begin{tabular}{ccc}
\hline Jenis Pekerjaan & Karyawan Aktual & $\begin{array}{c}\text { Karyawan Perhitungan } \\
\text { WPT/WKE }\end{array}$ \\
\hline Karyawan Panen & 33 & 34 \\
\hline
\end{tabular}

\section{KESIMPULAN}

Berdasarkan hasil pengamatan dan perhitungan peneliti yang telah dilakukan, maka peneliti dapat mengambil kesimpulan sebagai berikut:

1. Berdasarkan hasil pengamatan peneliti melalui karakteristik karyawan panen yang berpengaruh ialah karakteristik usia dan karakteristik tinggi badan, terbukti usia $20-29$ tahun lebih cepat mencapai target atau basis di bandingkan dengan umur 30 - 49 tahun. Dan karakteristik tinggi badan berpengaruh pada waktu mencapai target lebih cepat terbukti tinggi badan 170 - $179 \mathrm{~cm}$ lebih cepat mencapai target atau basis dibandingkan 150 - $159 \mathrm{~cm}$ karena kekuatan mendorong atau menarik lebih kuat pada tinggi badan.

2. Hasil pengamatan peneliti dari 16 responden karyawan panen waktu kerja produktif rata-rata $73,52 \%$, waktu tidak produktif $17,20 \%$ dan waktu pribadi $9,28 \%$ secara perhitungan penggunaan waktu karyawan panen sekitar 4,49 jam $(73,52 \%)$.

3. Hasil dari perhitungan kebutuhan karyawan panen dalam 1 afdeling mendapatkan hasil 33.644 dibulatkan menjadi 34 karyawan panen yang dibutuhkan dalam 1 afdeling $(763,33$ ha) melalui perhitungan dari waktu penyelesai tugas (WPT).

\section{DAFTAR PUSTAKA}

Bary M. A., Syuaib M.F dan Rachmat M. 2013. "Analisis beban kerja pada proses produksi Crude Palm Oil (CPO) dipabrik Mintak sawit dengan kapasitas 50 ton TBS/jam". Jurnal Teknologi Industri Pertanian. Vol 23 No. 3: 220-231.

Handoko S.,Putri N.T., Jonrinaldi. 2017. "Analisis Beban Kerja dan Kebutuhan Tenaga Kerja. VOL.16 NO. 2 (2017) 140-149.

Pahan, I. 2012. "Panduan Lengkap Kelapa sawit". Jakarta : Penerbit Swadaya. 146 hal.

Roidelindho, K. (2017). Penentuan Beban Kerja Dan Jumlah Tenaga Kerja Optimal. Jurnal Rekayasa Sistem Industri, Vol. 3, No. 1, 25-42.

Suwanto dan Priansa D.J. 2011. Manajemen SDM dalam Organisasi Publik dan Bisnis, Alfabeta, Bandung.

Sujahweni, V, W. (2015) Rumus Dan Data Dalam Analisis Statistika. Bandung. Alfabeta.

Sofiana, Y dan Yahya, S. 2015. "Manajemen Panen Kelapa Sawit (Elaeis guineensis Jacq.) Di Kebun Tambusai Kec. Tambusai, Kabupaten Rokan Hulu, Riau". Jurnal Bul.Agrohorti 2 (3): 213-220.

Wijaya, A., \& Andrijanto. (2014). Perbaikan Sistem Kerja Untuk Meningkatkan Efesiensi Waktu Produksi Di PT Berdikari Metal Engineering, Pada Departemen Press. Jurnal Universitas Kristen Maranatha. 
Setiawan, M.I.B., Rahman, A., Faradilla, dan Barry, M.A. .(2021) "Studi Kasus Analisis Beban Kerja Berdasarkan Waktu Kerja Karyawan Pada Unit Pemanenan Afdeling 1 Di Kebun Kelapa Sawit PT. XYZ", Jurnal Agriment, 6(2).

Yanto, \& Nyaliman B. (2017). Ergonomi Dasar-Dasar Study Waktu dan Gerakan Untuk Analisis Sistem Kerja. Jakarta: Penerbit Andi.

Yasin Sabana L. O. L 2020. Analisis Beban Kerja Untuk Menentukan Jumlah Optimal Karyawan Panen Kelapa Sawit PT Hutan Hijau Mas. Program Studi Pengelolaan Perkebunan. Perkebunan Politeknik Pertanian Negeri Samarinda. 28 hal. 